\title{
Hypoalbuminemia and Related Factors in Hemodialyzed Patients: A Study of Six Centers in Turkey
}

\section{Hemodiyaliz Hastalarında Hipoalbüminemi ve ilişskili Faktörler: Türkiye'de Altı Merkezli Bir Çalışma}

\author{
๑ Halil İbrahim Erdoğdu, ๑ Eray Atalay \\ Kafkas University Faculty of Medicine, Department of Internal Diseases, Kars, Turkey
}

\section{Abstract}

\begin{abstract}
Aim: It is known that low serum albumin levels are related to mortality in hemodialysis (HD) patients. In this study, it was aimed to determine factors which may affect serum albumin level and investigate any gender variation in serum albumin concentration.

Methods: The data of this study was obtained by the analysis of the records of 306 patients. The patients were divided into two groups; albumin $<3.8 \mathrm{~g} / \mathrm{dL}$ and $\geq 3.8 \mathrm{~g} / \mathrm{dL}$. Albumin was determined as a dependent variable of the study, while age, sex, dialysis adequacy parameters, C-reactive protein (CRP), anemia status and presence of diabetes mellitus were determined as independent variables. As statistical examination, chi-square test and logistic regression were used. A $p$ value of $<0.05$ was considered statistically significant (Confidence interval=95\%).
\end{abstract}

Results: The Odds ratio for hypoalbuminemia was 3.1 times higher for women compared to men $(\mathrm{Cl}: 1.6-6.0, \mathrm{p}=0.001), 5.5$ times higher for patients with $\mathrm{Kt} / \mathrm{V}<1.4(\mathrm{Cl}: 2.5-11.9, \mathrm{p}=0.001)$, 2.9 times higher for patients with $C R P>1.0 \mathrm{mg} / \mathrm{dL}(\mathrm{Cl}: 1.5-5.6$, $p=0.001)$ and was 4.9 times higher for patients with hemoglobin $(\mathrm{Hb})<11 \mathrm{~g} / \mathrm{dL}(\mathrm{Cl}: 2.6-9.2, \mathrm{p}=0.001)$.

Conclusion: These results indicate that when hypoalbuminemia is detected in HD patients, gender, adequacy of dialysis, Hb levels and causes of inflammation should be considered.

Keywords: Adequacy of hemodialysis, C-reactive protein, gender, hemodialysis, hypoalbuminemia
Öz

Amaç: Hemodiyaliz (HD) hastalarında düşük serum albümin seviyelerinin mortalite ile ilişkili olduğu bilinmektedir. Bu çalışmada serum albümin seviyesini etkileyebilecek faktörlerin ve albümin seviyesinin cinsiyetler arasında farklı olup olmadığının belirlenmesi amaçlandı.

Yöntemler: Bu çalışmanın verileri 306 hastanın verilerinin analizi ile elde edildi. Hastalar iki gruba ayrıldı; albümin $<3,8$ $\mathrm{g} / \mathrm{dL}$ ve $\geq 3,8 \mathrm{~g} / \mathrm{dL}$. Albümin çalışmanın bağımlı bir değişkeni olarak belirlenirken, yaş, cinsiyet, diyaliz yeterliliği parametreleri, C-reaktif protein (CRP), anemi durumu ve diabetes mellitus varlığı bağımsız değişken olarak belirlendi. İstatistiksel analizde ki-kare ve lojistik regresyon analizi kullanıldı. $\mathrm{P}<0,05$ değeri istatistiksel olarak anlamlı kabul edildi (Güven aralığı=\%95).

Bulgular: Hipoalbüminemi için Odds oranı kadınlarda erkeklere göre 3,1 kat (Cl: 1,6-6,0, $\mathrm{p}=0,001), \mathrm{Kt} / \mathrm{V}<1,4$ olanlarda 5,5 kat (Cl: 2,5-11,9, $p=0,001), C R P>1,0 \mathrm{mg} / \mathrm{dL}$ olan hastalarda 2,9 kat (Cl: 1,5-5,6, $p=0,001)$ ve hemoglobini $(\mathrm{Hb})<11 \mathrm{~g} / \mathrm{dL}$ olanlarda $4,9$ kat (Cl: 2,6-9,2, $\mathrm{p}=0,001)$ daha yüksekti.

Sonuç: Bu sonuçlar HD hastalarında hipoalbüminemi tespit edildiğinde cinsiyet, diyaliz yeterliliği, $\mathrm{Hb}$ ve enflamasyon nedenlerinin göz önünde bulundurulması gerektiğini göstermektedir.

Anahtar Sözcükler: Hemodiyaliz yeterliliği, C-reaktif protein, cinsiyet, hemodiyaliz, hipoalbüminemi
Address for Correspondence/Yazışma Adresi: Halil ibrahim Erdoğdu, Kafkas University Faculty of Medicine, Department of Internal Diseases, Kars, Turkey E-mail: halil-dr@hotmail.com ORCID: orcid.org/0000-0001-7755-4931

Received/Geliş Tarihi: 25 June 2019 Accepted/Kabul Tarihi: 10 August 2019
${ }^{\circ}$ Copyright 2019 by The Medical Bulletin of istanbul Haseki Training and Research Hospital The Medical Bulletin of Haseki published by Galenos Yayınevi. ${ }^{\bullet}$ Telif Hakkı 2019 istanbul Haseki Eğitim ve Araştırma Hastanesi Haseki Tıp Bülteni, Galenos Yayınevi tarafindan yayınlanmıştı. 


\section{Introduction}

Hypoalbuminemia is an important marker of proteinenergy wasting (PEW) in end-stage renal disease (ESRD) patients receiving maintenance hemodialysis (HD) treatment. Low serum albumin is suggested to be one of the key diagnostic criteria for clinical diagnosis of PEW by the International Society of Renal Nutrition and Metabolism (ISRNM) Expert Panel (1).

Hypoalbuminemia is associated with cardiovascular and all other causes of mortality in addition to deterioration in general clinical conditions. Therefore, it is recommended to keep the level of serum albumin $\geq 3.8 \mathrm{~g} / \mathrm{dL}$ (1). Albumin has a number of important physiological functions such as regulation of osmotic pressure and transportation of lipid, bile acids and metal ions. Therefore, in the case of hypoalbuminemia, these functions are deficient.

Various factors, such as intake of low protein due to inflammation and loss of appetite, cause hypoalbuminemia. Loss of protein in HD sessions, regulation of phosphorus and decrease in albumin synthesis may play a role in the development of hypoalbuminemia. Also, relatively low blood urea values before HD might be one of the reasons for inadequate protein intake (2-4).

Inflammation in ESRD is related to various reasons such as decreased clearance of proinflammatory cytokines, deterioration of PEW, inadequate food intake, decreased levels of antioxidants, oxidative stress, exposure to dialysis membranes and intravenous catheters (5). Various cytokines, such as C-reactive protein (CRP) and interleukin-6, cause vascular endothelial damage (6). Previous studies have shown the role of inflammation in both hypoalbuminemia and cardiovascular diseases $(2,7,8)$.

In this study, we aimed to analyze factors that may affect albumin levels, such as age, gender, body mass index (BMI), duration of dialysis, vascular access, dialysis adequacy parameters, serum CRP elevation, anemia status, erythropoietin (Epo), vitamin D treatment, and the presence of diabetes mellitus which is a major contributor to PEW rather than the association of hypoalbuminemia with ESRD-related diseases in HD patients $(1,2,4)$.

\section{Methods}

\section{Study Participants}

This cross-sectional study was conducted by analysing 306 patients' data collected in six HD centers in Kars, Ardahan and Iğdır provinces and Sarıkamış, Kağızman, and Göle districts in the Northeast Anatolia region of Turkey. In the present study, biocompatible low flux membrane was used. The blood flow rate and the dialysate flow rate ranged from 300 to $400 \mathrm{~mL} / \mathrm{min}$ and 500 to $800 \mathrm{~mL} / \mathrm{min}$, respectively. A bicarbonate-based dialysate was used in all patients.

The patients were receiving HD three times a week for 4 hours a day. Patients' assessments were obtained through analysis of medical and nutritional records. The demographic and clinical data including sex, age, dialysis vintage, blood flow and dialysate flow rates and presence of diabetes were collected.

Blood samples were drawn by using a uniform technique used in the HD clinics. Laboratory values, including serum concentration of blood urea nitrogen (BUN) and complete blood cell count, CRP, hemoglobin $(\mathrm{Hb})$, albumin, calcium and phosphorus, were measured monthly using an autoanalyzer. Serum parathyroid hormone (PTH) and ferritin levels were measured quarterly. The patient's biochemistry, complete blood count, $\mathrm{Kt} / \mathrm{V}$ and urea reduction rate (URR) data were averaged over the last three months, while hormone analysis results were averaged over the last two measurements. Since low phosphorus level is associated with hypoalbuminemia, the lower limit of reference range for phosphorus level (range=3.5-5.5 mg/dL) used by the central laboratory was taken for comparison of hypoalbuminemia (4).

We had records of 306 patients, but 24 patients were excluded from the study. Patients who received HD less than three months $(n=3)$, patients who received interdialytic or intradialytic parenteral nutrition $(n=1)$, patients with overhydration diagnosed by echocardiography and chest X-ray $(n=5)$, patients with metabolic acidosis $(n=3)$, guest patients $(n=5)$, patients who had transient elevation of CRP due to any acute pathology $(n=6)$ and patients who had chronic liver disease were excluded from the study $(\mathrm{n}=1)$. The patients were divided into two groups: those with albumin $\geq 3.8 \mathrm{~g} / \mathrm{dL}$ and $<3.8 \mathrm{~g} / \mathrm{dL}$ according to the ISRNM (1). Serum albumin was measured by the bromocresol green assay in the centers. By considering the recommendations of the Kidney Disease Outcomes Quality Initiative (KDOQI) clinical practice guideline for HD adequacy, pre-HD blood samples were taken before saline and heparin administration and after-HD blood samples were taken after blood pump rate was lowered to 100 $\mathrm{mL} / \mathrm{min}$ for 15 seconds $(4,9)$.

The URR was calculated using the formula URR $=100 \times(1$ postdialysis BUN/predialysis BUN) (10).

The conventional urea-kinetic measure known as single pool Kt/V was used to estimate the HD dose and it was calculated using Daugirdas' second generation formula. A $\mathrm{Kt} / \mathrm{V}$ of 1.4 or URR of $65 \%$ was accepted as target value $(9,11)$.

BMI was computed as the postdialysis body weight $(\mathrm{kg})$ divided by the square of the patient's height (meters). 
Postdialysis body weight was recorded with the subjects lightly dressed and without shoes according to ISRNM. A BMI of $23 \mathrm{~kg} / \mathrm{m}^{2}$ was accepted as limit value for the clinical diagnosis of PEW in $\operatorname{ESRD}(1,4)$.

Serum albumin level was a dependent variable in the study and the age of the patient, vascular access pathway, duration of dialysis, dialysis adequacy, BMI, presence of diabetes, CRP, anemia, low and high PTH levels, ferritin level, Epo level, vitamin D treatment (calcitriol or vitamin D analogs, a combination of calcimimetics with calcitriol or vitamin $\mathrm{D}$ analogs, only calcimimetics) were determined as independent variables. The two groups were compared. In addition to that, we examined Kt/ $\mathrm{V}$ according to gender in order to determine whether albumin level was different for men and women (12).

\section{Statistical Analysis}

For statistical evaluation, SPSS Statistics of Windows v.21.0 (SPSS; IBM Corporation, New York, USA) was used. The chi-square test was used in the analysis of the categorical variables. A p value of $<0.05$ and $95 \% \mathrm{Cl}$ were considered statistically significant). The binary logistic regression (Backward: LR) was applied to independent variables that were statistically significant in the chi-square test.
The study was conducted according to the principles of the Declaration of Helsinki and written informed consent was obtained from each patient. The protocol was approved by the Ethics Committee for Clinical Research, Medicine Faculty of Kafkas University (approval number: 31.01.2018/10), Kars, Turkey.

\section{Results}

The number of patients included in the study was 282 , with 119 women $(42.2 \%)$ and 163 men $(57.8 \%)$. The rate of patients with an albumin level of lower than $3.8 \mathrm{~g} / \mathrm{dL}$ was $55.4 \%$. The mean age of the patients was $61.5 \pm 15.5$ (range: was 20-98) years. The mean age of the females was $62.9 \pm 15.5$ and the males was $60.4 \pm 15.4$ years. $6.7 \%$ of females and $35.6 \%$ of males had a $\mathrm{Kt} / \mathrm{V}$ of $<1.4$ $(p=0.001)$.

Fifty-two-point-two percent of patients were aged 65 years and older and $47.8 \%$ were younger than 65 years of age (Table 1). The proportion of patients who underwent HD for five years or more was $42 \%$ and the rate of patients who underwent dialysis treatment with arteriovenous fistula (AVF) was found to be $78.4 \%$.

In Table 2, we present a binary comparison of independent variables including the dialysate adequacy parameters, anemia status, some biochemical and

\begin{tabular}{|c|c|c|c|c|c|}
\hline \multicolumn{2}{|l|}{ Independent variables } & \multicolumn{2}{|l|}{ Dependent variables } & \multirow{3}{*}{$\begin{array}{l}\text { Total } \\
\mathbf{n}(\%)\end{array}$} & \multirow{3}{*}{$p$} \\
\hline & & \multirow{2}{*}{$\begin{array}{l}\text { Albumin } \geq 3.8 \mathrm{~g} / \mathrm{dL} \\
\mathrm{n}(\%)\end{array}$} & \multirow{2}{*}{$\begin{array}{l}\text { Albumin }<3.8 \mathrm{~g} / \mathrm{dL} \\
\mathrm{n}(\%)\end{array}$} & & \\
\hline & & & & & \\
\hline \multirow[t]{2}{*}{ Age (years) } & $<65$ & $72(53.3)$ & $63(46.7)$ & $135(47.8)$ & \multirow[t]{2}{*}{0.005} \\
\hline & $\geq 65$ & $54(36.7)$ & $93(63.3)$ & $147(52.2)$ & \\
\hline \multirow[t]{2}{*}{ Gender } & Female & $41(34.5)$ & $78(65.5)$ & $119(42.2)$ & \multirow[t]{2}{*}{0.003} \\
\hline & Male & $85(52.1)$ & $78(47.9)$ & $163(57.8)$ & \\
\hline \multirow[t]{2}{*}{ HD Vintage (years) } & $<5$ & $74(45.1)$ & $90(54.9)$ & $164(58.0)$ & \multirow[t]{2}{*}{0.861} \\
\hline & $\geq 5$ & $52(44.1)$ & $66(55.9)$ & $118(42.0)$ & \\
\hline \multirow[t]{3}{*}{ Vascular access } & AVF & $106(48.0)$ & $115(52.0)$ & $221(78.4)$ & \multirow[t]{3}{*}{0.105} \\
\hline & CVC & $18(33.3)$ & $36(66.7)$ & $54(19.1)$ & \\
\hline & Graft (synthetic) & $2(28.6)$ & $5(71.4)$ & $7(2.5)$ & \\
\hline \multirow[t]{2}{*}{ Diabetes mellitus } & Yes & $32(37.2)$ & $54(62.8)$ & $86(30.5)$ & \multirow[t]{2}{*}{0.095} \\
\hline & No & $94(48.0)$ & $102(52.0)$ & $196(69.5)$ & \\
\hline \multirow[t]{2}{*}{ BMI $\left(\mathrm{kg} / \mathrm{m}^{2}\right)$} & $<23$ & $56(44.1)$ & $71(55.9)$ & $127(45.0)$ & \multirow[t]{2}{*}{0.858} \\
\hline & $\geq 23$ & $70(45.2)$ & $85(54.8)$ & $155(55.0)$ & \\
\hline \multirow[t]{2}{*}{ Eritropoietin treatments } & Yes & $96(40.5)$ & $141(59.5)$ & 237 (84.0) & \multirow[t]{2}{*}{0.001} \\
\hline & No & $30(66.7)$ & $15(33.3)$ & $45(16.0)$ & \\
\hline \multirow[t]{2}{*}{ Vitamin D treatments* } & Yes & $64(44.1)$ & $81(55.9)$ & $145(51.4)$ & \multirow[t]{2}{*}{0.850} \\
\hline & No & $62(45.3)$ & $75(54.7)$ & $137(48.6)$ & \\
\hline \multicolumn{2}{|l|}{ Total } & $126(44.6)$ & $156(55.4)$ & $282(100.0)$ & \\
\hline
\end{tabular}


hormonal values compared with the albumin level. There was a significant difference in Kt/V $(p=0.003)$, CRP $(p=0.001), H b(p=0.001)$, phosphorus $(p=0.029), P T H$ $>300(p=0.026)$ and ferritin $(p=0.019)$ between patients with and without hypoalbuminemia.

The results of logistic regression analysis are given in Table 3.

The risk of hypoalbuminemia was 2.9 times higher (Cl: 1.5-5.6, $p=0.001)$ in patients with $C R P>1.0 \mathrm{mg} / \mathrm{dL}$ than in those with $C R P \leq 1.0 \mathrm{mg} / \mathrm{dL}, 5.5$ times higher (Cl: 2,5-11.9, $\mathrm{p}=0.001)$ in patients with $\mathrm{Kt} / \mathrm{V}<1.4$ than in $\mathrm{Kt} / \mathrm{V} \geq 1.4,4.9$ times higher $(\mathrm{Cl}: 2.6-9.2, \mathrm{p}=0.001)$ in patients with $\mathrm{Hb}<11 \mathrm{~g} / \mathrm{dL}$ than in those with $\mathrm{Hb} \geq 11 \mathrm{~g}$ $\mathrm{dL}$, and 3.1 times higher $(\mathrm{Cl}: 1.6-6.0, \mathrm{p}=0.001)$ in female patients than in males.

Effect of gender on Kt/V, CRP and Biodemographic Parameters on gender is also given in Table 4.

There was a statistically significant difference in Kt/V and $H D$ vintage (years) between genders (Table 4).

The results of multiple linear regression analysis of independent variables, which were gender, $\mathrm{Kt} / \mathrm{V}, \mathrm{Hb}$ and CRP, compared with serum albumin are given in Table 5.

\section{Discussion}

In this study, it was aimed to determine the factors causing low albumin level, which is one of the criteria recommended by ISRNM expert panel for PEW diagnosis for patients who are undergoing HD therapy (1). Epidemiological studies have shown that low serum albumin levels increase mortality and are therefore used as a biochemical indicator $(13,14)$.

In the logistic regression analysis of the independent variables which had a significant difference in binary comparisons made for determining the factors such as $\mathrm{CRP}, \mathrm{Kt} / \mathrm{V}, \mathrm{Hb}$ and gender affecting albumin levels the factors causing hypoalbuminemia were determined in the multiple linear logistic regression analysis (Table 5). In a cohort study by Kalantar-Zadeh et al. (14), regardless of the cause of hypoalbuminemia, it was estimated that the population-attributable fraction of death due to baseline serum albumin $<3.8 \mathrm{~g} / \mathrm{dL}$ was $19 \%$, thus, $19 \%$ of deaths in patients undergoing maintenance HD could be prevented if serum albumin level was increased to $>3.8 \mathrm{~g} / \mathrm{dL}$. In the same study, it was found that a serum albumin level of 4.4 $\mathrm{g} / \mathrm{dL}$ or higher was associated with $48 \%$ higher survival compared to serum albumin $<3.8 \mathrm{~g} / \mathrm{dL}$.

Reduced renal clearance of pro-inflammatory cytokines in patients undergoing HD therapy, exposure of mononuclear cells to extracorporeal circulation and endotoxins, artificial grafts, presence of indwelling catheter, infections and various inflammatory diseases may contribute to inflammation $(2,8,15)$. Other

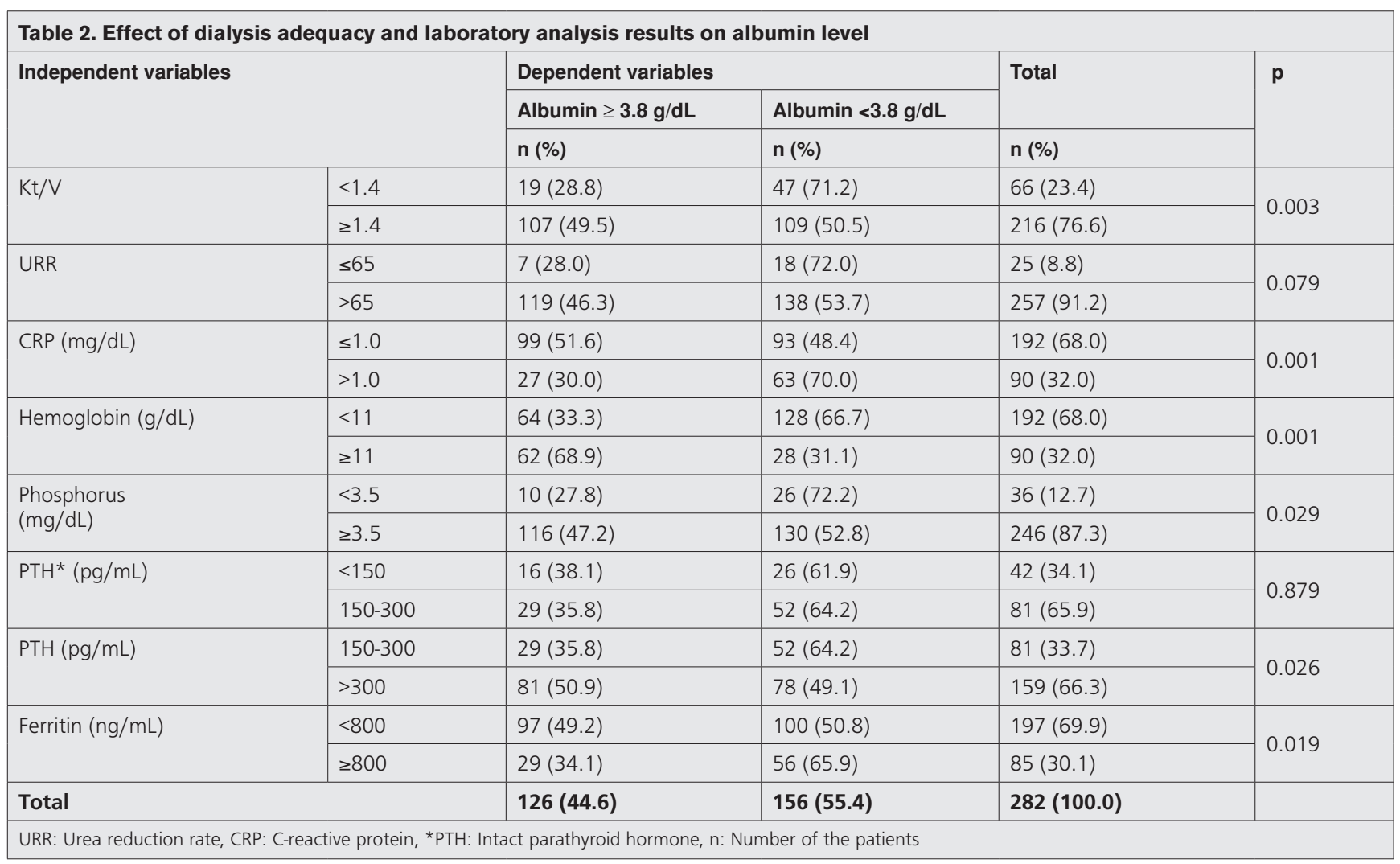


cytokines such as CRP and TNF-alpha may lead to protein-energy malnutrition by increasing catabolism and to hypoalbuminemia by suppressing appetite (16). In concordance with our study, previous studies demonstrated an inverse relationship between increased serum CRP levels and albumin levels (8). The normal range for CRP determined by the nephelometer method in the laboratories at the HD centers participating in the study was $0-0.5 \mathrm{mg} / \mathrm{dL}$. In the literature, although a low level of chronic inflammation was determined in $30-65 \%$ of HD patients, there is no consensus on a threshold value for CRP as an indicator of inflammation. Generally, 0.5-1.0 $\mathrm{mg} / \mathrm{dL}(5.0-10 \mathrm{mg} / \mathrm{L})$ is considered the threshold value for CRP (16). In the logistic regression analysis carried out in our study, hypoalbuminemia was found to be 2.9 times higher in patients with a a CRP level higher than $1.0 \mathrm{mg} /$ dL (Cl: 95\%, 1.5-5.6).

In their study, Kaysen et al. (8) found an inverse correlation between CRP and albumin level. Another study also reported that a $1 \mathrm{~g} / \mathrm{dL}$ decrease in serum albumin level was associated with inflammation and $47 \%$ increased mortality risk (17). However, in the case of inflammation, increased protein intake has also positive effect on the albumin level (18).

When the $\mathrm{Kt} / \mathrm{V}$, an independent variable, which was one of the dialysis adequacy parameters evaluated monthly, was calculated with logistic regression analysis, hypoalbuminemia was found to be 5.5 times higher in

\begin{tabular}{|c|c|c|c|c|c|c|c|}
\hline \multicolumn{8}{|c|}{ Dependent variable: Level of serum albumin $<3.8 \mathrm{~g} / \mathrm{dL}$} \\
\hline \multicolumn{2}{|l|}{ Independent variables } & B & S. E & Wald & Odds ratio & $95 \% \mathrm{Cl}$ & p \\
\hline \multirow[t]{2}{*}{ C-reactive protein $(\mathrm{mg} / \mathrm{dL})$} & $>1.0$ & 1.073 & 0.334 & 10.286 & 2.9 & \multirow[t]{2}{*}{$1.5-5.6$} & \multirow[t]{2}{*}{0.001} \\
\hline & $\leq 1.0$ & - & - & - & Reference & & \\
\hline \multirow[t]{2}{*}{$\mathrm{Kt} / \mathrm{V}$} & $<1.4$ & 1.699 & 0.397 & 18.340 & 5.5 & \multirow[t]{2}{*}{$2.5-11.9$} & \multirow[t]{2}{*}{0.001} \\
\hline & $\geq 1.4$ & - & - & - & Reference & & \\
\hline \multirow[t]{2}{*}{ Hemoglobin $(g / d L)$} & $<11$ & 1.595 & 0.319 & 25.060 & 4.9 & \multirow[t]{2}{*}{$2.6-9.2$} & \multirow[t]{2}{*}{0.001} \\
\hline & $\geq 11$ & - & - & - & Reference & & \\
\hline \multirow[t]{2}{*}{ Gender } & Female & 1.147 & 0.329 & 12.170 & 3.1 & \multirow[t]{2}{*}{$1.6-6.0$} & \multirow[t]{2}{*}{0.001} \\
\hline & Male & - & - & - & Reference & & \\
\hline
\end{tabular}

\begin{tabular}{|c|c|c|c|c|}
\hline \multicolumn{2}{|l|}{ Parameters } & \multirow{2}{*}{$\begin{array}{l}\text { Female } \\
\text { n (\%) }\end{array}$} & \multirow{2}{*}{$\begin{array}{l}\text { Male } \\
\text { n (\%) } \\
81(49.7)\end{array}$} & \multirow{3}{*}{$\begin{array}{l}\mathbf{p} \\
0.474\end{array}$} \\
\hline \multirow[t]{2}{*}{ Age (years) } & $<65$ & & & \\
\hline & $\geq 65$ & $65(54.6)$ & $82(50.3)$ & \\
\hline \multirow[t]{2}{*}{$\mathrm{Kt} / \mathrm{V}$} & $<1.4$ & $8(6.7)$ & $58(35,6)$ & \multirow[t]{2}{*}{0.001} \\
\hline & $\geq 1.4$ & $111(93.3)$ & 105 (64.4) & \\
\hline \multirow[t]{2}{*}{ HD vintage (years) } & $<5$ & $59(49.6)$ & 105 (64.4) & \multirow[t]{2}{*}{0.013} \\
\hline & $\geq 5$ & $60(50.4)$ & $58(35.6)$ & \\
\hline \multirow[t]{2}{*}{ CRP (mg/dL) } & $\leq 1.0$ & $74(62.2)$ & $118(72.4)$ & \multirow[t]{2}{*}{0.069} \\
\hline & $>1.0$ & $45(37.8)$ & $45(27.6)$ & \\
\hline \multirow[t]{3}{*}{ Vascular access } & AVF & $90(75.6)$ & $131(80.4)$ & \multirow[t]{3}{*}{0.546} \\
\hline & CVC (cuffed) & $25(21.0)$ & $29(17.8)$ & \\
\hline & Greft (synthetic) & $4(3.4)$ & $3(1.8)$ & \\
\hline \multirow[t]{2}{*}{ Diabetes mellitus } & Yes & $39(32.8)$ & $47(28.8)$ & \multirow[t]{2}{*}{0.478} \\
\hline & No & $80(67.2)$ & $116(71.2)$ & \\
\hline \multirow[t]{2}{*}{ BMI (kg/m²) } & $<23$ & $47(39.5)$ & $80(49.1)$ & \multirow[t]{2}{*}{0.110} \\
\hline & $\geq 23$ & $72(60.5)$ & $83(50.9)$ & \\
\hline Total & & $119(42.2)$ & $163(57.8)$ & \\
\hline
\end{tabular}




\begin{tabular}{|c|c|c|c|c|c|c|c|}
\hline \multicolumn{8}{|c|}{ Dependent variable: serum albumin } \\
\hline \multicolumn{8}{|c|}{ Model Summary (Method: Enter) } \\
\hline Model & $\mathbf{R}$ & $\mathbf{R}^{2}$ & Adj. $R^{2}$ & \multicolumn{4}{|c|}{ Standard error of the estimate } \\
\hline 1 & 0.456 & 0.208 & 0.197 & \multicolumn{4}{|l|}{0.41090} \\
\hline \multicolumn{8}{|l|}{ ANOVA } \\
\hline \multicolumn{2}{|l|}{ Model 1} & Sum of squares & Mean square & $\mathbf{F}$ & \multicolumn{3}{|l|}{ p } \\
\hline \multicolumn{2}{|l|}{ Regression } & 12.291 & 3.073 & \multirow[t]{3}{*}{18.200} & \multirow{3}{*}{\multicolumn{2}{|c|}{$<0.001$}} & \\
\hline Residual & & 46.768 & 0.169 & & & & \\
\hline Total & & 59.060 & & & & & \\
\hline \multicolumn{8}{|l|}{ Coefficients } \\
\hline \multirow{2}{*}{\multicolumn{2}{|c|}{ Model 1}} & \multicolumn{2}{|c|}{ Unstandardized coefficients } & Standardized coefficients & \multirow[t]{2}{*}{$\mathbf{T}$} & \multirow[t]{2}{*}{ p } & Collinearity statistics \\
\hline & & B & $\begin{array}{l}\text { Standard } \\
\text { error }\end{array}$ & $\beta$ & & & Tolerance \\
\hline (Constant) & & 1.840 & 0.262 & - & 7.013 & $<0.001$ & - \\
\hline $\mathrm{Kt} / \mathrm{V}$ & & 0.496 & 0.098 & 0.313 & 5.035 & $<0.001$ & 0.741 \\
\hline CRP $(\mathrm{mg} / \mathrm{dL})$ & & -0.029 & 0.011 & -0.148 & -2.714 & 0.007 & 0.955 \\
\hline Hemoglobin (g/dL) & & 0.090 & 0.016 & 0.319 & 5.788 & $<0.001$ & 0.939 \\
\hline Gender & & 0.185 & 0.058 & 0.200 & 3.197 & 0.002 & 0.734 \\
\hline
\end{tabular}

patients with $\mathrm{Kt} / \mathrm{V}<1.4$ than in patients with $\mathrm{Kt} / \mathrm{V} \geq 1.4(\mathrm{Cl}$ : 95\%, 2.5-11.9).

According to the $\mathrm{KDOQ}$ I clinical practice guidelines for HD adequacy, the minimum Kt/ $\mathrm{V}$ value for adequate dialysis is 1.2 and the target value is 1.4 (9). The average $\mathrm{Kt} / \mathrm{V}$ in the men and women in the centers participating in our study were $1.73 \pm 0.30$ and $1.44 \pm 0.30$, respectively. In addition, only six patients had a $\mathrm{Kt} / \mathrm{V}<1.2$. Therefore, statistical analysis was done with the level of 1.4 in the present study where the rate of hypoalbuminemia was $71.2 \%$ in the group with the $\mathrm{Kt} / \mathrm{V}<1.4$.

Unlike our study, Lertdumrongluk et al. (19) found that the greatest survival advantage of higher HD dose was observed in patients with a Kt/V 1.8-2.0 compared to the group whose spKt $/ \mathrm{V}$ value increased from $<1.2$ to $\geq 2$. 0 but they determined no relation between $\mathrm{Kt} / \mathrm{V}$ and albumin levels. Adequate dialysis may have a positive effect on hypoalbuminemia. Reduction of inflammatory cytokines may improve appetite and thus cause adequate protein intake (16).

According to the NKF-K/DOQI Clinical Practice Guidelines for Anemia of Chronic Kidney Disease, those with a $\mathrm{Hb}<11 \mathrm{~g} / \mathrm{dL}$ are considered anemic $(4,20)$. In the study, the proportion of Epo-treatment recipients was $84 \%$ and the rate of those who had anemia was $68 \%$. The reason for the higher percentage for Epo-therapy patients than the anemic ones was that Epo was given to maintain treatment in those with $\mathrm{Hb} 11-12 \mathrm{~g} / \mathrm{dL}$. In this study, hypoalbuminemia was found to be 4.9 times $(\mathrm{Cl}$ : $95 \%$ 2.6-9.2) higher in people who had a $\mathrm{Hb}$ level of $<11$ $\mathrm{g} / \mathrm{dL}$ when $\mathrm{Hb} \geq 11 \mathrm{~g} / \mathrm{dL}$ was taken as reference.

Previous studies have also examined the relationship between $\mathrm{Hb}$ and albumin levels. In a cross-sectional analysis, Kim et al. (21) found a correlation between elevation of serum albumin from $3.4 \mathrm{~g} / \mathrm{dL}$ to $4.2 \mathrm{~g} / \mathrm{dL}$ and elevation of $\mathrm{Hb}$ from $11.5 \mathrm{~g} / \mathrm{dL}$ to $12.3 \mathrm{~g} / \mathrm{dL}$. Although there was a significant difference between serum ferritin level and albumin level in the binary comparisons, no effect of ferritin was found in the logistic regression. It is well known that ferritin is a marker of both depot iron and acute or chronic inflammation. Ferritin levels in the presence of inflammation may increase iron levels independently. Ferritin levels in HD patients commonly range between 300 and $800 \mathrm{ng} / \mathrm{mL}$. If the ferritin level exceeds $800 \mathrm{ng} / \mathrm{mL}$, iron administration may be stopped and Epo and iron intake should be re-evaluated $(5,8,20,22)$. An increase in the level of hepcidin, the key regulator of iron metabolism, causes anemia in the case of inflammation (23).

In the study, a bilateral comparison of $\mathrm{Hb}$ and ferritin showed that the ferritin level was not greater than 800 $\mathrm{ng} / \mathrm{mL}$ in any patient with a $\mathrm{Hb}$ of $\geq 11 \mathrm{~g} / \mathrm{dL}(0 / 90)$. On the contrary, ferritin was $800 \mathrm{ng} / \mathrm{mL}$ or higher in $30.1 \%$ (85/282) of those with $\mathrm{Hb}<11 \mathrm{~g} / \mathrm{dL}$. High ferritin levels in HD patients are associated with severe anemia and Epo resistance (24). 
In our study, the albumin level was $<3.8 \mathrm{~g} / \mathrm{dL}$ in $65.5 \%$ of the females and $47.9 \%$ of the males (Table $1, p=0.003)$. When logistic regression analysis was performed with reference to the data obtained from men, hypoalbuminemia was 3.1 times more common (Cl: 95\%, 1.6-6.0) in females than in males. Fifty-point-four percent of women and $35.6 \%$ of males had a HD vintage of $>5$ years (Table 4). When the dialysis adequacy by gender was analyzed, it was found that for women the rate of $\mathrm{Kt} / \mathrm{V}$ $<1.4$ was only $6.7 \%(8 / 119)$, while the rate for men was $35.6 \%$ (58/163) (Table 4). These findings may suggest that when hypoalbuminemia is detected in female patients undergoing HD, either HD dose should be increased or factors such as normalized protein equivalent of total nitrogen appearance (nPNA) should be re-evaluated. In concordance with our study, in a large study in Japan, hypoalbuminemia was found to be more frequent in women than in men with similar Kt/V levels (12).

Although there was a statistically significant difference for hypoalbuminemia between patients with PTH >300 $\mathrm{pg} / \mathrm{mL}$ and those with 150-300 pg/mL, when we compared two separate levels of PTH as $<150 \mathrm{pg} / \mathrm{mL}$ and $>300 \mathrm{pg} / \mathrm{mL}$, there was no significant difference in logistic regression analysis. While protein is restricted in order to lower serum phosphorus levels, serum albumin may fall by decreasing protein intake. Although there was a statistically significant difference between serum phosphorus and albumin in the binary comparison, no effect was found in the logistic regression. In the cases of restriction of phosphorus for HD patients, albumin level may fall. This is called Phosphate Paradigm. Lowering serum phosphorus by restricting protein intake may lead to increased risk of death, however, controlling serum phosphorus without restricting dietary protein may provide improved survival in HD patients $(16,25)$. In our study, we did not determine any effect of age, URR, vascular access route, diabetes mellitus, Epo usage, vitamin D use and BMI on serum albumin. Additionally, these variables were not were not statistically significant factors for the development of hypoalbuminemia in the comparison of diabetic patients with nondiabetics, although $62.8 \%$ of diabetic patients had hypoalbuminemia ( $p=0.095)$. This may be related to the cut-off level for albumin in the study.

\section{Study Limitations}

The strength of our work is being multi-centered and contained clinical, laboratory and hormonal parameters. This is the first research done in the Northeast Anatolia region until now. However, it has some limitations. Firstly, it is a retrospective study. Secondly, measurements of nPNA, also known as normalized protein catabolic rate, are missing. When measuring nPNA, many parameters including residual renal clearance should be taken into consideration and patients should be under a constant diet. Otherwise, it may be found to be above or below its true value. Our third limitation is that we could not control whether our patients had a fixed diet or not.

\section{Conclusion}

We assume that in order to have the level of albumin at the recommended levels in HD, the causes of inflammation should be clarified to enable treatment of hypoalbuminemia. Although the dialysis efficacy was provided in women, no positive effect on hypoalbuminemia was detected. We suggest that future studies may focus on exogenous losses, increased fractional catabolic rate and decreased synthesis in the case of hypoalbuminemia. However, further large-scale studies investigating the relationship between adequacy of dialysis and albumin levels for gender are needed.

\section{Authorship Contributions}

Surgical and Medical Practices: H.I.E., E.A. Concept: H.I.E., E.A. Design: H.i.E., E.A. Data Collection or Processing: H.I.E., E.A. Analysis or Interpretation: H.I.E., E.A. Literature Search: H.I.E., E.A. Writing: H.I.E., E.A.

Conflict of Interest: No conflict of interest was declared by the authors.

Financial Disclosure: The authors declared that this study received no financial support.

\section{References}

1. Fouque D, Kalantar-Zadeh K, Kopple J, et al. A proposed nomenclature and diagnostic criteria for protein-energy wasting in acute and chronic kidney disease. Kidney Int 2008; 73:391-8.

2. Ikizler TA, Cano NJ, Franch $\mathrm{H}$, et al. International Society of Renal Nutrition and Metabolism. Prevention and treatment of protein energy wasting in chronic kidney disease patients: a consensus statement by the International Society of Renal Nutrition and Metabolism. Kidney Int 2013;84:1096-107.

3. Ikizler TA. Dietary protein restriction in CKD: the debate continues. Am J Kidney Dis 2009;53:189-91.

4. Fouque $D$, Vennegoor M, Wee PT, et al. EBPG guideline on nutrition. Nephrol Dial Transpl 2007;22:45-87.

5. Kalantar-Zadeh K, Ikizler TA, Block G, Avram MM, Kopple JD. Malnutrition-inflammation complex syndrome in dialysis patients: causes and consequences. Am J Kidney Dis 2003;42:864-81.

6. Zwaka TP, Hombach V, Torzewski J. C-reactive protein mediated low-density lipoprotein uptake by macrophages. Circulation 2001;103:1194-7.

7. Yeun JY, Levine RA, Mantadilok V, Kaysen GA. C-Reactive protein predicts all cause and cardiovascular mortality in hemodialysis patients. Am J Kidney Dis 2000;35:469-76. 
8. Kaysen GA, Dubin JA, Müller HG, Mitch WE, Rosales LM, Levin NW. Relationships among inflammation nutrition and physiologic mechanisms establishing albumin levels in hemodialysis patients. Kidney Int 2002;6:2240-9.

9. Daugirdas JT, Depner TA, Inrig J, et al. KDOQI clinical practice guideline for hemodialysis adequacy: 2015 update. Am J Kidney Dis 2015;66:884-930.

10. KDOQI clinical practice guideline and clinical practice recommendations: hemodialysis adequacy, peritoneal dialysis adequacy, and vascular access: Am J Kidney Dis 48(suppl 1): update 2006;S1-S322.

11. Owen WF. Status of hemodialysis adequacy in the United States: Does it account for improved patient survival? Am J Kidney Dis 1998;32:39-43.

12. Kimata N, Karaboyas A, Bieber BA, et al. Gender, low Kt/V, and mortality in Japanese hemodialysis patients: opportunities for improvement through modifiable practices. Hemodial Int 2014;18:596-606.

13. Combe C, Chauveau P, Laville M, et al. French Study Group Nutrition in Dialysis. Influence of nutritional factors and hemodialysis adequacy on the survival of 1,610 French patients. Am J Kidney Dis 2001;37(1 Suppl 2):S81-8.

14. Kalantar-Zadeh K, Kilpatrick RD, Kuwae N, et al. Revisiting mortality predictability of serum albumin in the dialysis population: time dependency, longitudinal changes and population-attributable fraction. Nephrol Dial Transplant 2005;20:1880-8.

15. Zaoui P, Hakim RM. The effects of the dialysis membrane on cytokine release. J Am Soc Nephrol 1994;4:1711-8.

16. Fouque D, Pelletier S, Mafra D, Chauveau P. Nutrition and chronic kidney disease. Kidney Int 2011;80:348-57.

17. de Mutsert R, Grootendorst DC, Indemans F, Boeschoten EW, Krediet RT, Dekker FW. Netherlands Cooperative Study on the
Adequacy of Dialysis-II Study Group. Association between serum albumin and mortality in dialysis patients is partly explained by inflammation, and not by malnutrition. J Ren Nutr 2009;19:127-35.

18. Kaysen GA, Chertow GM, Adhikarla R, Young B, Ronco C, Levin NW. Inflammation and dietary protein intake exert competing effects on serum albumin and creatinine in hemodialysis patients. Kidney Int 2001;60:333-40.

19. Lertdumrongluk P, Streja $E$, Rhee CM, et al. Dose of hemodialysis and survival: a marginal structural model analysis. Am J Nephrol 2014;39:383-91.

20. National Kidney Foundation anemia working group. "NKF-K/ DOQI Clinical Practice Guidelines for Anemia of Chronic Kidney Disease, 2000 Am J Kidney Dis 2001;37:182-238.

21. Kim Y, Molnar MZ, Rattanasompattikul M, et al. Relative contributions of inflammation and inadequate protein intake to hypoalbuminemia in patients on maintenance hemodialysis. Int Urol Nephrol 2013;45:215-27.

22. Kalantar-Zadeh K, Rodriguez RA, Humphreys MH. Association between serum ferritin and measures of inflammation, nutrition and iron in haemodialysis patients. Nephrol Dial Transpl 2004;19:141-9.

23. Stoian I, Manolescu B, Atanasiu V, Lupescu O, Buşu C. IL-6 STAT-3 - hepcidin: linking inflammation to the iron metabolism. Rom J Intern Med 2007;45:305-9.

24. Gunnell J, Yeun JY, Depner TA, Kaysen GA. Acute-phase response predicts erythropoietin resistance in hemodialysis and peritoneal dialysis patients. Ame J Kidney Dis 1999;33:6372.

25. Shinaberger CS, Greenland S, Kopple JD, et al. Is controlling phosphorus by decreasing dietary protein intake beneficial or harmful in persons with chronic kidney disease? Am J Clin Nutr 2008;88:1511-8 